\title{
MOTIVASI BELAJAR MAHASISWA PROGRAM STUDI TADRIS KIMIA DALAM MENGIKUTI MATA KULIAH PRAKTIKUM KIMIA DASAR
}

\author{
Ardian Trio Wicaksono \\ Program Studi Tadris Kimia, Fakultas Tarbiyah dan Keguruan, Universitas Islam Negeri Antasari \\ ardian.tw@uin-antasari.ac.id
}

Trining Puji Astutik

Program Studi Tadris Kimia, Fakultas Tarbiyah dan Keguruan, Universitas Islam Negeri Antasari ningtut@gmail.com

\begin{abstract}
Abstrak
Program Studi (Prodi) Tadris Kimia Fakultas Tarbiyah dan Keguruan (FTK) Universitas Islam Negeri (UIN) Antasari Banjarmasin pada tahun 2018 telah melaksanakan mata kuliah praktikum kimia dasar. Proses pembelajaran praktikum kimia dasar dilakukan di dalam kelas yang seharusnya dilakukan di laboratorium. Hal ini karena Prodi Tadris Kimia belum memiliki laboratorium kimia dasar. Sampai saat ini Prodi Tadris Kimia terus mempersiapkan dan berusaha memenuhi berbagai kebutuhan pembelajaran untuk mendukung proses pembelajaran. Ketiadaan laboratorium kimia dasar sebagai penunjang mata kuliah praktikum kimia dasar dimungkinkan dapat menimbulkan masalah yakni mengganggu jalannya proses belajar mengajar dan mempengaruhi motivasi belajar mahasiswa dalam mempelajari kimia dasar. Tujuan dari penelitian ini untuk mengetahui motivasi belajar mahasiswa Prodi Tadris Kimia dalam mengikuti mata kuliah praktikum kimia dasar dan faktor faktor yang mempengaruhi motivasi belajar mahasiswa Prodi Tadris Kimia dalam mengikuti mata kuliah praktikum kimia dasar. Jenis penelitian yang dilakukan adalah penelitian lapangan menggunakan pendekatan kualitatif. Teknik pengumpulan data dilakukan melalui angket, wawancara dan dokumenter. Hasil penelitian menunjukkan bahwa motivasi belajar mahasiswa Prodi Tadris Kimia dalam mengikuti mata kuliah praktikum kimia dasar tergolong sedang/cukup. Faktor faktor yang mempengaruhi motivasi belajar mahasiswa Prodi Tadris Kimia dalam mengikuti mata kuliah praktikum kimia dasar terdiri atas faktor internal dan faktor eksternal.
\end{abstract}

Kata Kunci: Motivasi, Kuliah, Praktikum Kimia Dasar.

\begin{abstract}
The Tadris Chemistry Study Program of the Tarbiyah and Teaching Faculty of the Antasari State Islamic University Banjarmasin in 2018 has carried out basic chemistry practicum courses. The basic chemistry practicum learning process is carried out in the classroom that should be done in a laboratory. This is because Tadris Chemistry Study Program does not yet have a basic chemistry laboratory. Until now Tadris Chemistry Study Program continues to prepare and try to meet various learning needs to support the learning process. The absence of a basic chemistry laboratory as a support for basic chemistry practicum courses may cause problems that interfere with the course of the teaching and learning process and affect student motivation in learning basic chemistry. The purpose of this study was to determine the learning motivation of students of Tadris Chemistry Study Program in following the basic chemistry practicum course and the factors that influence the learning motivation of Tadris Chemistry Study Program students in taking a basic chemistry practicum course. This type of research is field research using a qualitative approach. Data collection techniques carried out through questionnaires, interviews and documentary. The results showed that the learning motivation of Tadris Chemistry Study Program students in taking the basic chemistry practicum course was classified as moderate / sufficient. Factors influencing the learning motivation of students of Tadris Chemistry Study Program in following the basic chemistry practicum course consist of internal factors and external factors.
\end{abstract}

Keywords: Motivation, Lecture, Basic Chemistry Practicum. 


\section{PENDAHULUAN}

Laboratorium merupakan tempat untuk mengaplikasikan teori keilmuan, pengajuan teoritis, pembuktian uji coba, penelitian dan sebangainya dengan menggunakan alat bantu yang menjadi kelengkapan dari fasilitas dengan kuantitas dan kualitas yang memadai (Depdiknas, 2002). Laboratorium pendidikan yang selanjutnya disebut laboratorium adalah unit penunjang akademik pada lembaga pendidikan, berupa ruangan tertutup atau terbuka, bersifat permanen atau bergerak, dikelola secara sistematis untuk kegiatan pengujian, kalibrasi, dan/atau produksi dalam skala terbatas, dengan menggunakan peralatan dan bahan berdasarkan metode kelimuan tertentu, dalam rangka pelaksanaan pendidikan, penelitian, dan/atau pengabdian kepada masyarakat (Permenpan RB No 03, 2010). Berdasarkan paparan tersebut maka perlunya adanya laboratorium kimia sebagai penunjang dalam pembelajaran. Praktikum kimia dasar merupakan salah mata kuliah yang membahas tentang konsep dasar ilmu kimia melalui berbagai percobaan. Mata kuliah ini ditawarkan pada semester II yang terdiri atas 2 sks yakni 1 sks teori dan 1 sks praktikum. 1 sks praktikum tersebut memerlukan laboratorium kimia dasar untuk melaksanakan kegiatan praktikum.

Kegiatan praktikum dapat mengembangkan keterampilan dasar melakukan eksperimen dan menjadi wahana belajar pendekatan ilmiah serta dapat menunjang pemahaman mahasiswa terhadap materi pelajaran. Selain itu, praktikum juga memberikan kesempatan kepada mahasiswa untuk memenuhi dorongan rasa ingin tahu dan ingin bisa sehingga pada akhirnya praktikum dapat membangkitkan motivasi belajar sains (Emda, 2014).

Motivasi diartikan sebagai dorongan mental yang menggerakkan dan mengarahkan perilaku manusia, termasuk perilaku belajar (Dimyati dan Mudjiono, 2006). Motivasi juga dapat diartikan sebagai perubahan dalam diri seseorang yang ditandai dengan timbulnya perasaan dan reaksi untuk mencapai tujuan (Hamalik, 2007). Berdasarkan paparan tersebut, maka motivasi dapat diartikan sebagai dorongan atau keinginan yang muncul dalam diri seseorang untuk mencapai tujuan tetentu.

Prodi Tadris Kimia pada tahun 2018 ini telah melaksanakan mata kuliah praktikum kimia dasar. Proses pembelajaran praktikum kimia dasar dilakukan di dalam kelas. Ketiadaan laboratorium kimia dasar sebagai penunjang mata kuliah praktikum kimia dasar dimungkinkan dapat menimbulkan masalah yakni mengganggu jalannya proses belajar mengajar dan mempengaruhi motivasi belajar mahasiswa dalam mempelajari kimia dasar. Oleh karena itu, tujuan dalam penelitian ini untuk mengetahui motivasi belajar mahasiswa Prodi Tadris Kimia dalam mengikuti mata kuliah praktikum kimia dasar dan faktor faktor yang mempengaruhi motivasi belajar mahasiswa Prodi Tadris Kimia dalam mengikuti mata kuliah praktikum kimia dasar.

Wiji (2014) mengungkapkan bahwa profil motivasi mahasiswa calon guru kimia berada pada kategori sedang, kecuali untuk mahasiswa tingkat I. Hal ini karena mahasiswa tingkat I belum memiliki target kinerja ketika belajar kimia di tingkat perguruan tinggi. Mereka masih belum menyadari kompetensi yang dimiliki dan belum memiliki keinginan untuk menunjukkan kemampuannya. Selain itu, keterbatasan interaksi antara mahasiswa dengan dosen dan dengan mahasiswa lainnya menyebabkan stimulus lingkungan belajar juga rendah. Mukhlis (2017). mengungkapkan bahwa perkuliahan dengan pembelajaran model problem solving materi stoikimetri pada mata kuliah Kimia Dasar I, berpengaruh terhadap peningkatan motivasi belajar mahasiswa. Selain itu, penerapan pembelajaran model model problem solving, dapat menambah semangat belajar mahasiswa dalam menyelesaikan setiap permasalahan stoikiometri. Berdasarkan penelitian penelitian tersebut peneliti dapat mengetahui kesimpulan dari masing masing kajian, sehingga dapat dijadikan dasar dan perbandingan untuk mengetahui motivasi belajar mahasiswa Program Studi Tadris Kimia dalam mengikuti mata kuliah praktikum kimia dasar.

Robbin (2003:208) menyatakan bahwa motivasi berasal dari kata motif, artinya 
keadaan dalam diri seseorang yang mendorong untuk bertindak melakukan suatu kegiatan dalam mencapai tujuan. Motivasi adalah keseluruhan daya penggerak di dalam diri siswa yang menimbulkan kegiatan belajar, yang menjamin kelangsungan kegiatan belajar dan memebrikan arah kegiatan belajar sehingga tujuan yang dikehendaki oleh subyek belajar tercapai (Sardiman, 2010:75). Nimran (2005:47) mendefinisikan motivasi adalah keadaan dimana usaha dan kemauan keras seseorang diarahkan kepada pencapaian hasil-hasil tertentu. Hasil-hasil yang dimaksud bisa berupa: produktivitas dan kehadiran atau perilaku kerja kreatifnya. Berdasarkan pengertian mengenai motivasi di atas dapat disimpulkan bahwa motivasi merupakan suatu dorongan yang dimiliki seseorang untuk melakukan sesuatu, dan juga sebagai pemberi arah dalam tingkah lakunya, salah satunya dorongan seseorang untuk belajar.

Ngalim (2003:72) menyebutkan motivasi mengandung tiga komponen pokok: (1) menggerakan; (2) motivasi juga mengarahkan atau menyalurkan tingkah laku; dan (3) menopang dan menjaga tingkah laku. Pada dasarnya motivasi itu dapat muncul dari diri sendiri maupun dari orang lain, sehingga para mahasiswa mampu meningkatkan motivasi belajarnya bisa karena dirinya sendiri maupun dari orang lain. Hamalik (2003: 175) menjelaskan fungsi motivasi antara lain: mendorong timbulnya kelakuan atau suatu perbuatan. Perbuatan belajar akan terjadi apabila seseorang tersebut memiliki motivasi, sebagai pengarah, artinya dapat menjadi jalan agar mampu menuju arah yang ingin dicapai, sebagai penggerak, berfungsi sebagai mesin bagi mobil. Besar kecilnya motivasi akan menentukan cepat atau lambatnya suatu pekerjaan. Berdasarkan fungsi motivasi diatas dapat disimpulkan bahwa fungsi motivasi adalah memberikan arah dalam meraih yang diinginkan, menentukan sikap atau tingkah laku yang akan dilakukan untuk mendapatkan apa yang diinginkan dan juga sebagai mendorong seseorang untuk melakukan aktivitas.

Perilaku belajar seseorang dapat dilihat dari perubahan-perubahan yang terjadi pada individu yang bersangkutan, karena perubahan itu menunjukkan individu tersebut telah mengalami perilaku belajar. Sugihartono dkk (2007: 76), menjelaskan ciri-ciri perilaku belajar sebagai berikut perubahan: 1) tingkah laku terjadi secara sadar; 2) bersifat kontinyu dan fungsional; 3) bersifat positif dan aktif; 4) bersifat permanen; 5) belajar bertujuan atau terarah; 6) mencangkup seluruh aspek tingkah laku. Berdasarkan penjelasan di atas maka ciri-ciri perilaku belajar ditandai dengan perubahan tingkah laku yang terjadi pada individu, baik itu perubahan tingkah laku yang terjadi secara sadar, perubahan bersifat positif maupun perubahan yang terarah.

Ngalim (2006:107) mengemukakan bahwa prestasi belajar dilatarbelakangi oleh dua faktor, yaitu (a) internal dan (b) eksternal. Faktor internal meliputi: minat, motivasi, cara belajar, kematangan dan kesiapan. Faktor eksternal meliputi: guru, lingkungan sekolah, keluarga, lingkungan masyarakat. Salah satu faktor internal yang mempengaruhi prestasi belajar adalah motivasi belajar. Motivasi mendorong seseorang untuk melakukan sesuatu sehingga mencapai tujuan. Jika siswa terdorong untuk melakukan belajar, maka akan terjadi suatu pembelajaran yang efektif yang pada akhirnya akan menghasilkan prestasi belajar yang tinggi.

Mata kuliah praktikum kimia dasar merupakan mata kuliah wajib yang harus dikuasai oleh mahasiswa Prodi Tadris Kimia. Pada pembelajaran praktikum kimia dasar mahasiswa akan diberikan pengalaman dalam melakukan percobaan dan pengamatan terhadap gejala-gejala kimia yang meliputi: ciri ciri reaksi kimia, pemisahan dan pemurnian zat secara spesifik, struktur lewis dan model molekul, model molekul senyawa organik, sifat periodik unsur, volume molar gas hidrogen, rumus empiri senyawa, pereaksi pembatas, stoikiometri dan kalor reaksi suatu reaksi kimia.

\section{METODE}

Jenis penelitian yang peneliti lakukan adalah penelitian lapangan yang bertujuan untuk mengetahui motivasi belajar mahasiwa Prodi Tadris Kimia dalam mengikuti mata kuliah praktikum 
kimia dasar dan faktor-faktor yang mempengaruhinya. Penelitian ini mengunakan pendekatan kualititatif yaitu menyampaikan fakta dan mendeskripsikannya. Data dalam penelitian ini terdiri atas 2 jenis yaitu data pokok berupa data motivasi belajar mahasiswa Prodi Tadris Kimia dalam mengikuti mata kuliah praktikum kimia dasar dan data penunjang berupa sejarah singkat berdirinya Prodi Tadris Kimia. sumber data dalam penelitian ini adalah mahasiswa Prodi Tadris Kimia angkatan 2017 yang telah menempuh mata kuliah praktikum kimia dasar, dosen pengampu mata kuliah kimia dasar, ketua dan sekretaris beserta staf Prodi Tadris Kimia.

Teknik pengumpulan data dalam penelitian ini menggunakan beberapa teknik, yaitu: (1) angket, untuk mengetahui secara langsung motivasi belajar mahasiswa Prodi Tadris Kimia dalam mengikuti mata kuliah praktikum kimia dasar, (2) wawancara, ditujukan kepada dosen pengampu mata kuliah kimia dasar untuk mengetahui faktorfaktor yang mempengaruhi motivasi belajar mahasiswa Prodi Tadris Kimia dalam mengikuti mata kuliah praktikum kimia dasar, dan (3) dokumenter, untuk menelaah berkas atau catatan penting yang berkaitan dengan data-data yang diperlukan.

Teknik analisis data yang digunakan dalam penelitian ini adalah teknik deskriptif kualitatif, melalui tahapan: reduksi, display dan verifikasi. Pada tahap reduksi diupayakan menemukan hal-hal pokok tentang data pokok penelitian, yaitu motivasi belajar mahasiswa Prodi Tadris Kimia dalam mengikuti mata kuliah praktikum kimia dasar dan faktor yang mempengaruhinya. Pada tahap display dilakukan perangkuman informasi dengan susunan yang sistematis, sehingga tema sentral yang berhubungan dengan motivasi belajar mahasiswa Prodi Tadris Kimia dalam mengikuti mata kuliah praktikum kimia dasar dapat diketahui dengan mudah. Tahap berikutnya adalah tahapan verifikasi yakni dilakukan pemberian makna yang relevan atas kesimpulan yang diambil.

\section{HASIL DAN PEMBAHASAN}

Motivasi Belajar Mahasiswa Prodi Tadris Kimia dalam Mengikuti Mata Kuliah Praktikum Kimia Dasar

Penyebaran angket dilakukan kepada seluruh mahasiswa Program Studi Tadris Kimia angkatan 2017 sebagai responden yang berjumlah 9 (sembilan) orang dengan menggunakan 10 (sepuluh) pertanyaan yaitu: (1) Apakah Anda telah menempuh mata kuliah praktikum kimia dasar pada semester genap tahun 2017/2018?; (2) Materi apa saja yang telah Anda pelajari selama menempuh mata kuliah praktikum kimia dasar?, (3) Saat menempuh mata kuliah praktikum kimia dasar, apakah materi yang diajarkan bersifat teori saja, praktikum saja, atau kombinasi antara teori dan praktikum?, (4) Berapa besaran persentase pembelajaran kimia dasar menggunakan teori dan persentase pembelajaran kimia dasar melalui praktikum?, (5) Menurut Anda, sarana apa saja yang sangat dibutuhkan dalam pembelajaran praktikum kimia dasar?, (6) Apakah keberadaan laboratorium kimia dasar sangat diperlukan dalam pembelajaran kimia dasar?, (7) Apakah keberadaan laboratorium kimia dasar mempengaruhi motivasi Anda dalam mengikuti mata kuliah praktikum kimia dasar?, (8) Apakah Anda tetap memiliki semangat mengikuti mata kuliah praktikum kimia dasar tanpa adanya laboratorium kimia dasar?, (9) Bagaimana cara Anda membangun motivasi belajar dalam mengikuti mata kuliah praktikum kimia dasar tanpa adanya laboratorium kimia dasar?, dan (10) Apa harapan Anda terhadap pimpinan lembaga dan prodi tadris kimia terkait laboratorium kimia dasar?.

Motivasi adalah proses internal yang mendorong seseorang melakukan kegiatan atau tugas tertentu untuk mencapai tujuan dan terjadi dalam rentang waktu tertentu 
(Hadi, 2016). Motivasi merupakan salah satu unsur penting yang harus diperhatikan oleh guru atau dosen dalam pembelajaran agar pembelajaran yang terjadi dapat berjalan efektif (Arends, 2012; Brophy, 2004; Palmer, 2005). Pada penelitian ini motivasi belajar dikhususkan dalam mengikuti mata kuliah kimia dasar.

Berdasarkan hasil penyebaran angket diketahui bahwa seluruh mahasiswa Prodi Tadris Kimia angkatan 2017 telah menempuh mata kuliah praktikum kimia dasar pada semester genap tahun 2017/2018. Hal ini karena mata kuliah praktikum kimia dasar merupakan mata kuliah wajib yang harus diambil oleh mahasiswa Prodi Tadris Kimia dan ditawarkan pada semester II yakni semester genap tahun 2017/2018. Seluruh mahasiswa belum bisa menyebutkan secara lengkap, benar dan terurut tentang materi materi yang telah dipelajari selama menempuh mata kuliah kimia dasar. Hal ini terjadi karena pola pikir yang dibangun belum tersusun dengan baik sehingga mengakibatkan kesulitan dalam menyebutkan materi materi yang telah dipelajari dalam praktikum kimia dasar. Materi materi yang dipelajari dalam praktikum kimia dasar untuk angkatan 2017 membahas tentang ciri ciri reaksi kimia, pemisahan dan pemurnian zat secara spesifik, struktur lewis dan model molekul, model molekul senyawa organik, sifat periodik unsur, volume molar gas hidrogen, rumus empiri senyawa, pereaksi pembatas, stoikiometri dan kalor reaksi suatu reaksi kimia.

Pembelajaran yang dilakukan dalam praktikum kimia dasar adalah kombinasi antara teori dan praktikum. Hal ini sesuai dengan pernyataan seluruh mahasiswa yang terdapat dalan angket menyatakan bahwa pada saat menempuh mata kuliah praktikum kimia dasar materi yang diajarkan bersifat kombinasi antara teori dan praktikum.

Besaran persentase pelaksanaan teori dan praktikum pada mata kuliah praktikum kimia dasar berbeda beda antara mahasiswa yang satu dengan mahasiswa yang lainnya menurut hasil angket. Hasil rata rata besaran persentase pelaksanaan teori dan praktikum adalah $90 \%$ melalui teori dan $10 \%$ melalui praktikum. Praktikum yang dilakukan bersifat sederhana berupa identifikasi proses proses kimia yang terjadi dalam kehidupan sehari hari, seperti proses larutnya gula di dalam air dan bergeraknya partikel partikel udara saat terkena sinar/cahaya lampu LCD dalam kelas. Hasil wawancara dengan dosen pengampu mata kuliah kimia dasar menyebutkan bahwa pembelajaran praktikum juga dapat dilakukan melalui pengamatan video video praktikum kimia dalam sosial media (virtual laboratory).

Jaya (2012) menyatakan bahwa laboratorium virtual merupakan sistem yang dapat digunakan untuk mendukung sistem praktikum yang berjalan secara konvensional, dengan adanya laboratorium virtual ini dapat memberikan kesempatan kepada siswa khususnya untuk melakukan praktikum baik melalui atau tanpa akses internet sehingga siswa tersebut tidak perlu hadir untuk mengikuti praktikum di ruang laboratorium. Menurut Puspita (2008) menyatakan bahwa laboratorium virtual dapat menghasilkan pembelajaran yang efektif karena siswa dapat belajar sendiri secara aktif tanpa bantuan instruktur ataupun asisten seperti sistem yang berjalan, dengan format tampilan berbasis web cukup membantu siswa untuk dapat mengikuti praktikum secara mandiri. Penggunaan laboratorium virtual sementara untuk saat ini terjadi karena sarana mendasar yang diperlukan dalam pembelajaran kimia dasar berupa laboratorium kimia dasar masih dalam proses pengadaan.

Pengadaan laboratorium kimia dasar juga harus dilengkapi dengan berbagai macam sarana sarana pendukung lainnya. Berikut sarana sarana pendukung lainnya yang diperlukan oleh mahasiswa berdasarkan hasil penyebaran angket: (1) alat alat laboratorium dan bahan bahan kimia, (2) peraga/model struktur atom, (3) alat pelindung diri seperti: kaca mata, sarung tangan dan masker, (4) buku buku kimia, (5) buku petunjuk praktikum, dan (6) Wifi. Sarana sarana tersebut sangat diperlukan untuk mendukung kelancaran proses pembelajaran dalam mengikuti mata kuliah dasar.

Keberadaan laboratorium kimia dasar sangat diperlukan dalam pembelajaran kimia dasar. Pentingnya keberadaan laboratorium 
kimia dasar menurut mahasiswa Prodi Tadris Kimia angkatan 2017 karena: (1) memerlukan bukti nyata dari teori yang dijelaskan agar kami dapat menjelaskan kembali sesuai dengan pemahaman kami masing masing, (2) melalui praktikum kami dapat mempraktekkan teori yang disampaikan sehingga lebih efektif, (3) agar mudah memahami dan mengaplikasikan dalam pembelajaran, (4) terdapat beberapa materi kimia dasar yang memerlukan praktikum untuk lebih memahamkan mahasiswa, (5) akan lebih mengerti terkait reaksi ketika dilakukan praktikum, dan (6) laboratorium merupakan elemen yang tidak boleh ditiadakan di jurusan tadris kimia. Berdasarkan penjelasan penjelasan yang telah dipaparkan di atas dapat diketahui bahwa laboratorium kimia dasar sangat diperlukan untuk mendukung proses pembelajaran kimia dasar.

Pembelajaran kimia dasar tanpa adanya laboratorium kimia dasar dapat mempengaruhi motivasi belajar mahasiswa dalam mengikuti pembelajaran kimia dasar. Hal tersebut dapat dibuktikan melalui angket yang menunjukkan bahwa keberadaan laboratorium kimia dasar yang saat ini belum ada mempengaruhi motivasi seluruh mahasiswa dalam mengikuti mata kuliah kimia dasar. Hasil angket menunjukkan bahwa hal tersebut terjadi karena: (1) jika pembelajaran yang dilakukan hanya berupa teori maka untuk mencapai pemahaman sangat sulit karena kami dapat memahami pembelajaran apabila ada objek secara langsung, (2) dengan diadakannya laboratorium saya akan bekerja keras untuk menyelesaikan tugas tugas perkuliahan, (3) melalui laboratorium kita dapat melihat langsung reaksi reaksi yang telah dijelaskan dibuku dan mengetahui hal hal yang terdapat di laboratorium, (4) motivasi saya saat masuk jurusan ini agar dapat melakukan praktikum di laboratorium yang sebenarnya bukan seperti waktu saya duduk di bangku SMA yang belum memiliki laboratorium, (5) jika ada laboratorium saya akan lebih semangat dari biasanya, (6) sebagian anak anak lebih suka terjun ke lapangan yaitu laboratorium sehingga lebih mudah untuk mengingat alur praktikum, dan (7) dengan adanya laboratorium jurusan kami dapat melakukan eksperimen eksperimen, sehingga sebagai mahasiswa saya menjadi senang dan termotivasi dengan kimia ini.

Ketiadaan laboratorium kimia dasar tidak mengurangi semangat untuk tetap belajar dan menuntut ilmu. Hal ini dapat dibuktikan dari hasil angket yang menunjukkan bahwa: (1) 67\% mahasiswa tetap memiliki semangat dalam mengikuti mata kuliah praktikum kimia dasar meskipun tanpa adanya laboratorium kimia dasar, (2) $11 \%$ mahasiswa kurang memiliki semangat dalam mengikuti mata kuliah praktikum kimia dasar tanpa adanya laboratorium kimia dasar, dan (3) $22 \%$ mahasiswa tidak memiliki semangat dalam mengikuti mata kuliah praktikum kimia dasar tanpa adanya laboratorium kimia dasar.

Berdasarkan penjelasan penjelasan yang telah dipaparkan di atas dapat diketahui bahwa motivasi belajar mahasiswa Prodi Tadris Kimia dalam mengikuti mata kuliah praktikum kimia dasar tergolong sedang/cukup. Hal ini karena dalam mengikuti pembelajaran praktikum kimia dasar yang belum memiliki laboratorium kimia dasar mahasiswa tetap berusaha mengikuti pembelajaran praktikum kimia dasar dengan cukup baik dan cenderung pasif dalam kelas. Hal ini juga sesuai dengan hasil wawancara yang dilakukan dengan dosen pengampu mata kuliah kimia dasar bahwa motivasi belajar mahasiswa kimia dalam mengikuti mata kuliah kimia dasar cukup termotivasi tetapi kurang aktif dalam menyampaikan pertanyaan dan pendapat. Oleh karena itu perlu adanya upaya untuk meningkatkan motivasi belajar mahasiswa kimia agar memiliki motivasi belajar yang lebih baik lagi dan aktif dalam menyampaikan pertanyaan dan pendapat.

Banyak cara yang dapat digunakan sebagai upaya untuk meningkatkan motivasi, karena motivasi merupakan suatu proses psikologis yang mencerminkan sikap. Sardiman (2010:92-95) menjelaskan ada beberapa contoh dan cara untuk menumbuhkan motivasi dalam kegiatan belajar di sekolah, antara lain: (1) memberi angka; (2) hadiah; (3) saingan atau kompetisi; (4) ego-involvement; (5) memberi ulangan; (6) mengetahui hasil; (7) 
pujian; (8) hukuman; (9) hasrat untuk belajar; (10) minat; dan (11) tujuan yang diakui.

Memberi angka biasanya akan lebih membuat peserta didik menjadi semangat belajar, karena angka merupakan simbol dari perolehan nilainya. Pemberian hadiah akan membuat peserta didik berlomba-lomba untuk mendapatkan hadiah tersebut, sehingga hadiah dapat menjadi motivasi bagi peserta didik. Saingan ataupun kompetisi akan menjadikan peserta didik berlombalomba untuk menjadi yang terbaik. Egoinvolvement merupakan salah satu bentuk motivasi yang sangat penting, karena menumbuhkan kesadaran kepada siswa agar merasakan pentingnya tugas dan menerimanya sebagai tantangan. Cara lain untuk menumbuhkan motivasi yaitu dengan cara memberi ulangan, karena dapat memotivasi siswa untuk belajar. Hasil yang baik, apabila diketahui oleh siswa, maka itu dapat lebih mendorong siswa untuk lebih giat belajar lagi. Pujian merupakan motivasi yang baik, diberikan kepada siswa oleh guru ketika siswa tersebut melakukan hal positif. Hukuman dapat menjadi motivasi bagi siswa, apabila penyampaiannya diberikan secara bijak serta tepat, agar siswa dapat memahami apa maksud siswa itu diberi hukuman. Minat peserta didik terhadap proses belajar dapat ditunjukkan dengan cara partisipasi siswa terhadap kegiatan pembelajaran. Kesimpulan dari berbagai upaya meningkatkan motivasi di atas bahwa motivasi dapat ditingkatkan melalui beberapa upaya antara lain memberikan penghargaan, memberikan hadiah dan juga adanya persaingan pada saat kegiatan pembelajaran berlangsung (Sardiman, 2010:92-95).

\section{Faktor Faktor yang Mempengaruhi Motivasi Belajar Mahasiswa Prodi Tadris Kimia dalam Mengikuti Mata Kuliah Praktikum Kimia Dasar}

Hamalik (2003:158) menjelaskan bahwa faktor-faktor yang mempengaruhi belajar salah satunya adalah adanya kemauan yang dapat mendorong belajar dan sebaliknya tidak adanya kemauan dapat memperlemah belajar. Ngalim (2006:107) mengemukakan bahwa prestasi belajar dilatarbelakangi oleh dua faktor, yaitu (a) internal dan (b) eksternal. Faktor internal meliputi: minat, motivasi, cara belajar, kematangan dan kesiapan. Faktor eksternal meliputi: guru, lingkungan sekolah, keluarga, lingkungan masyarakat.

Belajar tentu saja dipengaruhi beberapa faktor, karena setiap individu yang belajar pasti terjadi karena adanya dorongan dari dalam dirinya sendiri, maupun dorongan dari luar dirinya. Sugihartono (2007:76) menyatakan bahwa ada dua faktor yang mempengaruhi belajar yaitu internal dan eksternal. Faktor internal adalah faktor yang ada dalam diri individu yang sedang belajar. Faktor internal meliputi faktor jasmaniah dan faktor psikologis. Faktor eksternal adalah faktor yang ada di luar diri individu. Faktor eksternal yang berpengaruh dalam belajar meliputi faktor keluarga, sekolah, dan faktor masyarakat.

Berdasarkan hasil penyebaran angket diketahui bahwa motivasi belajar mahasiswa Prodi Tadris Kimia dalam mengikuti mata kuliah praktikum kimia dasar tergolong sedang/cukup. Hal ini dapat disebabkan oleh beberapa faktor yang dapat diketahui melalui hasil penyebaran angket. Faktor faktor tersebut dapat dibedakan menjadi faktor internal dan faktor internal.

Faktor internal yang mempengaruhi motivasi belajar mahasiswa Prodi Tadris Kimia dalam mengikuti mata kuliah praktikum kimia dasar yakni: (1) ketiadaan laboratorium mengakibatkan mahasiswa mencoba bereksperimen sendiri dan cenderung menimbulkan dampak negatif bagi sekitar karena tidak ada pantauan dari dosen, (2) mengingat orang tua yang telah membiayai dan tidak ingin melakukan hal yang sia sia serta tetap bersyukur masih bisa belajar walaupun tanpa laboratorium, (3) kesungguhan ingin memperdalam kimia dengan belajar banyak teori dahulu sebelum adanya laboratorium, dan (4) dengan selalu percaya bahwa suatu saat pasti akan ada laboratorium untuk jurusan kimia.

Selain faktor internal, terdapat juga faktor eksternal yang mempengaruhi motivasi belajar mahasiswa Prodi Tadris Kimia dalam mengikuti mata kuliah praktikum kimia dasar yakni: (1) berusaha menyenangi dosennya, dosen yang ramah 
dan menyenangkan agar kami tidak bosan dengan materi atau dengan mengadakan penayangan video, dan (2) mencari informasi di media sosial berupa video tentang praktikum praktikum kimia terkait materi yang dipelajari pada pertemuan tersebut.

\section{SIMPULAN}

\section{DAFTAR PUSTAKA}

Arend, R.I. 2012. Learning to Teach (9 ed). New York: Mc Graw-Hill.

Brophy, J. 2004. Motivating Student to Learn (2ed). New Jersey: Lawrence Erlbaum Associates (LEA).

Depdiknas. 2002. SPTK-21. Jakarta: Depdiknas.

Dimyati, \& Mudjiono. 2006. Belajar dan Pembelajaran. Jakarta: Rineka Cipta.

Emda, A. 2014. Laboratorium sebagai Sarana Pembelajaran Kimia dalam Meningkatkan Pengetahuan dan Keterampilan Kerja Ilmiah. Lantanida Journal, Vol. 2 No. 2.

Hadi, W.P. 2016. Analisis Motivasi Mahasiswa Program Studi IPA pada Mata Kuliah Kimia Dasar 2 dengan Bahan Ajar Berbahasa Inggris. Prosiding Seminar Nasional Pendidikan IPA Pascasarjana UM, Vol 1, ISBN: 978-602-9286-21-2.

Hamalik, O. 2003. Perencanaan Pengajaran Berdasarkan Pendekatan Sistem. Jakarta; Bumi Aksara.

--------. 2007. Proses Belajar Mengajar. Jakarta: PT. Bumi Aksara.

Jaya, H. 2012. Pengembangan Laboratorium Virtual untuk Kegiatan Praktikum dan Mem fasilitasi Pendidikan Karakter di SMK. Jurnal Pendidikan Vokasi, Vol 2, Nomor 1.

Mukhlis. 2017. Meningkatkan Motivasi Belajar Mahasiswa melalui Pembelajaran Model Problem Solving Materi Stoikiometri. Lantanida Journal, Vol. 5 No. 2, 93-196.

Ngalim, P. 2003. Psikologi Pendidikan. Bandung: Remaja Rosdakarya.
Berdasarkan hasil penelitian dan pembahasan, maka diperoleh simpulan sebagai berikut: (1) motivasi belajar mahasiswa Prodi Tadris Kimia dalam mengikuti mata kuliah kimia dasar tergolong sedang/cukup, dan (2) faktor-faktor yang mempengaruhi motivasi belajar mahasiswa Prodi Tadris Kimia dalam mengikuti mata kuliah kimia dasar berupa faktor internal dan faktor eksternal.

$\begin{array}{lcr}\text { Pendidikan. } & \begin{array}{c}2006 . \\ \text { Bandung: }\end{array} & \text { Psikologi } \\ \text { Remaja }\end{array}$
Media: Surabaya.

Palmer, D. 2005. A Motivational View of Constructivist-informed Teaching. Research Report. International Journal of Science Education, 27(15):18531881.

Peraturan Menteri Negara Pendayagunaan Aparatur Negara dan Reformasi Birokrasi, (Nomor 03, 2010), tentang Jabatan Fungsional Pranata Laboratorium Pendidikan dan Angka Kreditnya.

Puspita, R. (2008). Sistem Informasi Aplikasi Virtual Lab Pada Laboratorium Sistem Informasi Universitas Gunadarma. Proceeding, Seminar Ilmiah Nasional Komputer dan Sistem Intelijen (KOMMIT 2008) Auditorium Universitas Gunadarma, Depok.

Robbin, P.S. 2003. Perilaku Organisasi. Jakarta: PT. Gramedia.

Sardiman, A.M. 2010. Interaksi dan Motivasi Belajar Mengajar. Jakarta: PT. Raja Grafindo Persada.

Sugihartono, Fathiyah, K.N.; Harahap, F; Setiawati, F.A. Nurhayati, S.R. 2007. Psikologi Pendidikan. Yogyakarta: UNY Press.

Wiji, L., Wahyu, S., Muhammad A.K. Martoprawiro. 2014. Profil Motivasi Belajar Mahasiswa Calon Guru Kimia dan Korelasinya terhadap Model Mental. Jurnal Pengajaran MIPA, Volume 19, Nomor 2, Oktober 2014, hlm. 233-240. 